\title{
Improvements in Microstructure Homogenization and Mechanical Properties of Diffusion-Alloyed Steel Compact by the Addition of Cr-Containing Powders
}

\author{
M.W. WU, K.S. HWANG, H.S. HUANG, and K.S. NARASIMHAN \\ The use of diffusion-alloyed powders for fabricating powder metal parts, despite alleviating the \\ segregation problem of the alloying elements while retaining good compressibility, still cannot attain \\ homogeneous microstructure in as-sintered products. The presence of soft Ni-rich areas and pores \\ causes poor mechanical properties compared to those of wrought steel counterparts. This study \\ investigated the effects of adding $0.5 \mathrm{wt}$ pct $\mathrm{Cr}$, which was introduced in the $316 \mathrm{~L}$ stainless steel \\ powder form, on the microstructure and mechanical properties of diffusion-alloyed $\mathrm{Fe}-4 \mathrm{Ni}-1.5 \mathrm{Cu}-$ \\ 0.5Mo-0.5C (Metal Powder Industries Federation (MPIF) FD-0405) steels. The results show that \\ weak Ni-rich areas were present in the $\mathrm{Cr}$-free specimen when sintered at $1120{ }^{\circ} \mathrm{C}$ and $1250{ }^{\circ} \mathrm{C}$. \\ These areas were lean in carbon because of the strong repelling effect between $\mathrm{Ni}$ and $\mathrm{C}$. With the \\ addition of $316 \mathrm{~L}$ powders, the $\mathrm{Cr}$ was uniformly distributed and helped eliminate the soft Ni-rich \\ areas, particularly in specimens sintered at $1250{ }^{\circ} \mathrm{C}$. The distribution of carbon also improved. With a \\ more uniform distribution of $\mathrm{Ni}$ and $\mathrm{C}$, and more homogeneous microstructure, which consisted \\ mainly of bainite and martensite, the mechanical properties of the $\mathrm{Fe}-4 \mathrm{Ni}-1.5 \mathrm{Cu}-0.5 \mathrm{Mo}-0.5 \mathrm{C}$ diffu- \\ sion alloy steels were improved significantly.
}

\section{INTRODUCTION}

THE primitive method of making powder metal (P/M) products consists of compacting mixed elemental powders, followed by sintering. This mixing method creates segregation problems during powder handling and compaction and thus causes inhomogeneous microstructure in sintered products. As a result, the dimensional control and mechanical properties of $\mathrm{P} / \mathrm{M}$ parts are inadequate. An intuitive approach to solving this problem is to use prealloyed steel powders. However, the poor compressibility of the hard prealloyed powder has prohibited its wide application. Another alternative is to employ diffusion-alloyed powders, for which iron powders and alloying elemental powders are diffusion bonded together at low temperatures. ${ }^{[1-4]}$ These powders alleviate the segregation problem while maintaining good compressibility. However, the as-sintered microstructure of this powder, while improved, is still not homogeneous, unless extremely long sintering times or high sintering temperatures are employed. For example, in $\mathrm{Ni}$-containing $\mathrm{Fe}-4 \mathrm{Ni}-1.5 \mathrm{Cu}-0.5 \mathrm{Mo}-0.5 \mathrm{C}$ alloys, which are designated by the Metal Powder Industries Federation (MPIF) as FD-0405, many Ni-rich areas are still present when the industrial sintering practices are used. ${ }^{[1,2,4]}$ They are mostly found in the surface regions of iron powders, and such ringlike structures are known as the signature of this alloy. These soft Ni-rich areas have been blamed

M.W. WU, Graduate Student, and K.S. HWANG, Professor, are with the Department of Materials Science and Engineering, National Taiwan University, Taipei, 106, Taiwan, Republic of China. Contact e-mail: kshwang@ccms.ntu.edu.tw H.S. HUANG, Researcher, is with the Material and Chemical Research Laboratories, ITRI, Taiwan, Republic of China. K.S. NARASIMHAN, Vice President, Technology, is with Hoeganaes Corp., Cinnaminson, NJ 08077-2017.

Manuscript submitted November 7, 2005. for the facilitation of crack propagation during mechanical testing. ${ }^{[5,6,7]}$

The reason why Ni is difficult to homogenize is possibly that it has a slower diffusion rate in iron than those of other alloying elements, such as $\mathrm{C}$, Mo, and $\mathrm{Cr}^{[8]}$ Moreover, Ni has poor affinity with carbon, compared to other popular alloying elements such as $\mathrm{Cr}$ and Mo. ${ }^{[9]}$ Thus, it is likely that the carbon distribution will not be uniform either, when such Ni-rich areas are present. Due to the inhomogeneous alloying and microstructure, the full benefits of the alloy design for such diffusion-alloyed steel powders cannot be attained. ${ }^{[4]}$ In view of these problems, a better understanding of the causes of the inhomogeneous microstructure and a new method for improvement are required.

Since $\mathrm{Cr}$ is a strong carbide former, which could change the chemical potential of carbon in Ni-rich phases, it is possible that the presence of $\mathrm{Cr}$ in Ni-rich areas would increase the carbon content inside and help carbon homogenization. ${ }^{[9]}$ The reduction of the repelling effect between $\mathrm{Ni}$ and $\mathrm{C}$, if proved to be true, may also help improve the distribution of $\mathrm{Ni}$ in the $\mathrm{C}$-containing matrix. Moreover, $\mathrm{Cr}$ has a faster diffusion rate than Ni. This fulfills the prerequisite that $\mathrm{Cr}$ should be in the matrix prior to the formation of Ni-rich areas, if such hypotheses are correct. However, the use of $\mathrm{Cr}$ as an alloying element, which is a good strengthening element in wrought steels, is rare in powder metal parts. The difficulty comes from its high oxygen affinity. ${ }^{[10]}$ Thus, low-dew-point and high-temperature sintering are required to prevent the oxidation of $\mathrm{Cr}^{[11,12]}$ This creates problems for regular powder metal industries. This problem can be alleviated by reducing the activity of $\mathrm{Cr}$ using $\mathrm{Cr}$-containing prealloyed powders. Since $316 \mathrm{~L}$ stainless steel powders contain 16 to $18 \mathrm{wt}$ pet $\mathrm{Cr}$ and are usually readily available in most powder metal plants, they could serve as a source for $\mathrm{Cr}$ alloying. 
Because very limited research on understanding the cause of the uneven $\mathrm{Ni}$ distribution, not to mention the methods for improvement, has been reported, the objective of this study was thus to examine the effects of 316L stainless steel addition on the microstructure and mechanical properties of diffusion-alloyed FD-0405 P/M steels.

\section{EXPERIMENTAL PROCEDURE}

The base powder used in this study was diffusion-alloyed Fe-4Ni-1.5Cu-0.5Mo steel powder that conformed to the MPIF FD-0405 standard. For the addition of chromium, 3 wt pet $316 \mathrm{~L}$ powder or 0.5 wt pet $\mathrm{Cr}$ was introduced during the mixing process. Table I shows the characteristics of these two powders. The diffusion-alloyed powder was designated as material $\mathrm{A}$. The material that was admixed with $316 \mathrm{~L}$ powder was designated as material $\mathrm{B}$. The final compositions of materials A and B are listed in Table II. Both of these materials were mixed with $0.6 \mathrm{wt}$ pct graphite powder and $0.75 \mathrm{wt}$ pct ethylene bis-stearamide, which is a lubricant, in a $\mathrm{V}$-cone mixer for 30 minutes. The admixed powder was compacted into tensile bars per MPIF standard 10 at a pressure of approximately $500 \mathrm{MPa}$. The green densities of the tensile bars were maintained at $6.85 \mathrm{~g} / \mathrm{cm}^{3}$. The debinding was carried out by holding the green specimens at $550{ }^{\circ} \mathrm{C}$ for 15 minutes to remove the lubricant. After debinding, these specimens were subsequently sintered at $1120{ }^{\circ} \mathrm{C}$ for 30 minutes or at $1250{ }^{\circ} \mathrm{C}$ for 1 hour

Table I. The Characteristics of Diffusion-Alloyed Powder and 316L Stainless Steel Powder Used in This Study

\begin{tabular}{|c|c|c|}
\hline Type & $\begin{array}{l}\text { Diffusion Alloyed } \\
\text { Powder }\end{array}$ & $\begin{array}{l}\text { 316L Stainless } \\
\text { Steel Powder }\end{array}$ \\
\hline Designation & Distaloy 4800A & PF-20F \\
\hline $\begin{array}{l}\text { Average particle size } \\
\quad \text { (Laser scattering method) }\end{array}$ & $\begin{array}{l}D_{10}=16.27 \mu \mathrm{m} \\
D_{50}=46.85 \mu \mathrm{m} \\
D_{90}=100.21 \mu \mathrm{m}\end{array}$ & $\begin{array}{l}D_{10}=5.75 \mu \mathrm{m} \\
D_{50}=13.67 \mu \mathrm{m} \\
D_{90}=27.42 \mu \mathrm{m}\end{array}$ \\
\hline Tap density, $\mathrm{g} / \mathrm{cm}^{3}$ & 3.43 & 3.85 \\
\hline Apparent density, $\mathrm{g} / \mathrm{cm}^{3}$ & 3.02 & NA \\
\hline Theoretical density, $\mathrm{g} / \mathrm{cm}^{3}$ & 7.91 & 7.92 \\
\hline Flow Rate, s/50 g & 27.5 & NA \\
\hline \multicolumn{3}{|l|}{ Composition } \\
\hline Ni, wt pct & 3.84 & 12.7 \\
\hline Mo, wt pet & 0.5 & 2.1 \\
\hline $\mathrm{Cu}$, wt pet & 1.5 & - \\
\hline Cr, wt pet & - & 16.46 \\
\hline $\mathrm{C}$ & 0.01 & 0.025 \\
\hline $\mathrm{O}$ & 0.13 & 0.307 \\
\hline Supplier & $\begin{array}{l}\text { Hoeganaes Corp. } \\
\text { (Cinnaminson, NJ) }\end{array}$ & $\begin{array}{l}\text { Epson ATMIX } \\
\text { (Aomori, Japan) }\end{array}$ \\
\hline
\end{tabular}

Table II. The Compositions of Materials A and B Used in This Study

\begin{tabular}{|c|c|c|c|c|c|}
\hline Designation & $\begin{array}{c}\mathrm{Ni} \\
\text { (Wt Pct) }\end{array}$ & $\begin{array}{c}\text { Mo } \\
\text { (Wt Pct) }\end{array}$ & $\begin{array}{c}\mathrm{Cu} \\
\text { (Wt Pct) }\end{array}$ & $\begin{array}{c}\mathrm{Cr} \\
\text { (Wt Pct) }\end{array}$ & $\begin{array}{c}\mathrm{C} \\
\text { (Wt Pct) }\end{array}$ \\
\hline A & 3.84 & 0.50 & 1.50 & - & 0.60 \\
\hline $\begin{array}{c}B(A+3 w t \\
\text { pct } 316 L)\end{array}$ & 4.22 & 0.56 & 1.50 & 0.49 & 0.58 \\
\hline
\end{tabular}

in a tube furnace, followed by furnace cooling. Both debinding and sintering were performed in an atmosphere of 91 pct $\mathrm{N}_{2}-9$ pct $\mathrm{H}_{2}$. The dew point of the atmosphere was below $-45^{\circ} \mathrm{C}$. The average cooling rate of the furnace was $0.1{ }^{\circ} \mathrm{C} / \mathrm{s}$ in the temperature range of $900{ }^{\circ} \mathrm{C}$ to $300{ }^{\circ} \mathrm{C}$.

The densities of the sintered specimens were measured using the Archimedes' method. Tensile tests were performed using a strain rate of $0.0224 / \mathrm{min}$ (MTS, AG10TE, Shimadzu Co., Kyoto, Japan). The data reported were averages of eight specimens. For microstructure observations, sintered tensile bars were ground, polished, and etched with a mixed solution of 4 pct nital and 2 pct picral. The microstructure was examined under a scanning electron microscope (SEM, XL-30, Philips, Eindhoven, Holland) or a conventional optical microscope. An electron probe microanalyzer (EPMA, JEOL JXA-8600SX, Japan Electron Optics Ltd., Tokyo, Japan) was also used to investigate the distribution of the alloying elements. Since the $\mathrm{Ni}$ distribution was quite inhomogeneous, an electron backscattering diffraction analyzer (EBSD, FE-SEM, JSM-6500F, JEOL, Tokyo, Japan) was used to identify the structures of the unknown phases. To understand the evolution of phase changes during cooling, a continuous cooling transformation (CCT) graph was built by placing specimens in a dilatometer (SETSYS TMA16/18, SETRAM, Caluire, France), heated to $900{ }^{\circ} \mathrm{C}$ and then cooled with various cooling rates. The microhardness was measured using a Vickers hardness (MVK-E2, Akashi Co., Tokyo, Japan) tester and the load applied was $10 \mathrm{gf}$.

\section{RESULTS AND DISCUSSION}

\section{A. Mechanical Properties}

The mechanical properties of as-sintered materials A and $\mathrm{B}$ (material A $+316 \mathrm{~L}$ ) along with the densities are listed in Table III. The data show that after 30 minutes of sintering at $1120{ }^{\circ} \mathrm{C}$, the tensile strength of material $\mathrm{B}$ was higher than that of material $\mathrm{A}$, the plain diffusion-alloyed powder, by 14 pct. The hardness also increased from HRB 83 to HRB 88. However, the elongation decreased slightly. These changes could not be attributed to the small density differences, nor were these improvements caused by the carbon content, because material $\mathrm{B}$ had a higher hardness but a lower carbon content.

After $1250{ }^{\circ} \mathrm{C}$ sintering, the tensile strength of material $\mathrm{B}$ significantly increased. This material was again higher than material A, by 28 pct. The hardness of material B also increased to HRB 99, higher than the HRB 91 of material A. These improvements, caused by the $316 \mathrm{~L}$ powder addition, were not attributed to the differences in density or carbon content, because all the numbers were very close. It was more likely that the increases in tensile strength and hardness were caused by the improvement in microstructure.

\section{B. Microstructure of Fe-4Ni-1.5Cu-0.5Mo-0.5C P/M Steels}

Figure 1 shows the typical microstructure of diffusionalloyed $\mathrm{Fe}-4 \mathrm{Ni}-1.5 \mathrm{Cu}-0.5 \mathrm{Mo}-0.5 \mathrm{C}$ steels (material A) 
Table III. The Measured Values Along with Standard Deviations of Density, Carbon Content, and Mechanical Properties of Materials A and B

\begin{tabular}{|c|c|c|c|c|c|c|}
\hline Material & $\begin{array}{c}\text { Sintering } \\
\text { Temperature }\left({ }^{\circ} \mathrm{C}\right)\end{array}$ & $\begin{array}{l}\text { Density } \\
\left(\mathrm{g} / \mathrm{cm}^{3}\right)\end{array}$ & $\begin{array}{l}\text { Carbon Content } \\
\text { (Pct) }\end{array}$ & $\begin{array}{l}\text { Hardness } \\
\text { (HRB) }\end{array}$ & $\begin{array}{c}\text { Tensile Strength } \\
(\mathrm{MPa})\end{array}$ & $\begin{array}{l}\text { Elongation } \\
\quad(\mathrm{Pct})\end{array}$ \\
\hline \multirow[t]{2}{*}{$\mathrm{A}$} & 1120 & $6.85(0.02)$ & $0.51(0.01)$ & $83(3)$ & $530(13)$ & $2.3(0.3)$ \\
\hline & 1250 & $6.90(0.01)$ & $0.48(0.01)$ & 91 (4) & $626(11)$ & $2.0(0.3)$ \\
\hline \multirow[t]{2}{*}{ B } & 1120 & $6.86(0.03)$ & $0.48(0.01)$ & 88 (4) & 603 (14) & $1.9(0.2)$ \\
\hline & 1250 & $6.93(0.03)$ & $0.45(0.02)$ & 99 (3) & 801 (10) & $1.5(0.2)$ \\
\hline
\end{tabular}

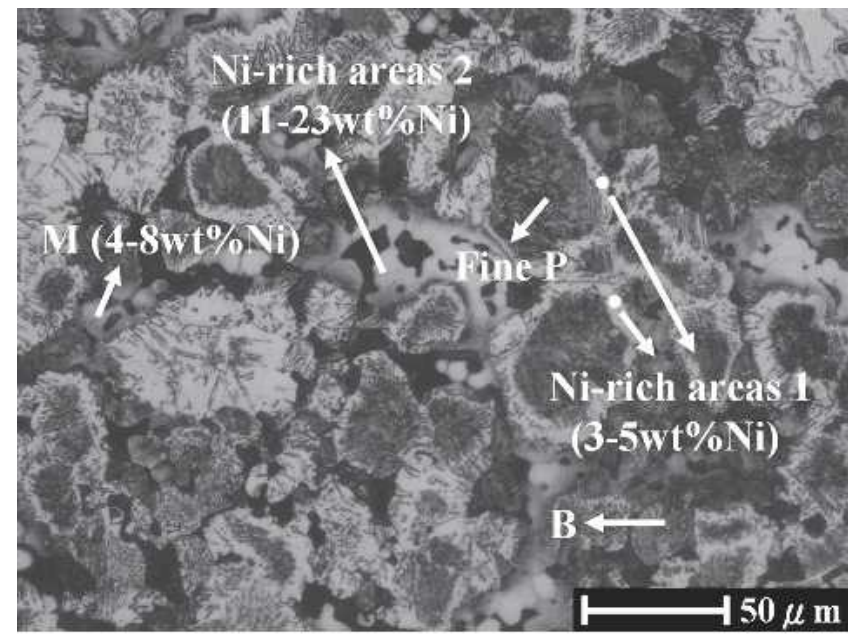

(a)

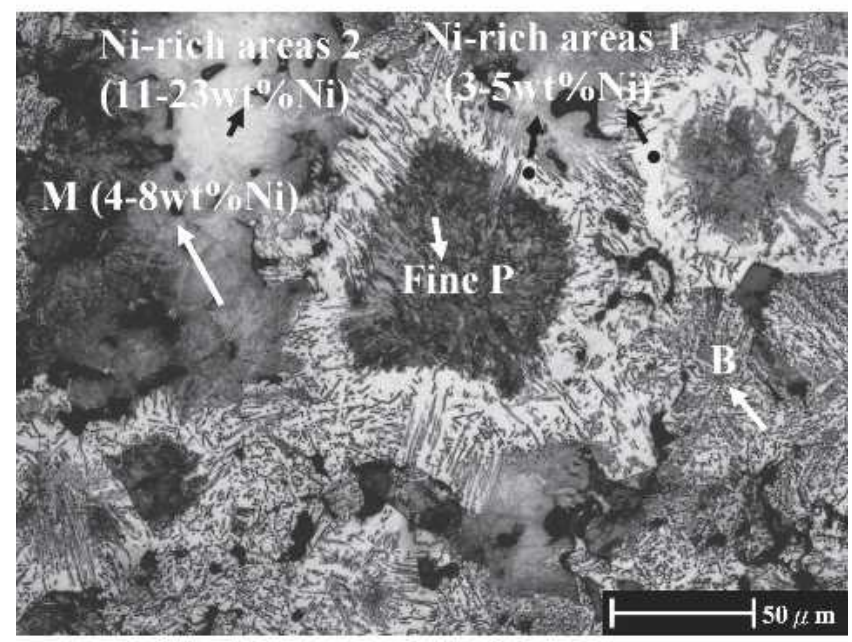

(b)

Fig. 1-The microstructure of the diffusion-alloyed Fe-4Ni-1.5Cu-0.5Mo$0.5 \mathrm{C}$ steel that was sintered at (a) $1120^{\circ} \mathrm{C}$ for $30 \mathrm{~min}$ and $(b) 1250^{\circ} \mathrm{C}$ for $1 \mathrm{~h}$.

after sintering at $1120{ }^{\circ} \mathrm{C}$ and $1250{ }^{\circ} \mathrm{C}$. After $1120{ }^{\circ} \mathrm{C}$ sintering, the interior of the iron powder consisted mainly of pearlite, of which the $\mathrm{Ni}$ content was less than $0.1 \mathrm{wt}$ pct, as measured by an EPMA. The hardness measured ranged from HV170 to HV250. In contrast, the areas at the periphery of the iron powders were enriched with 3 to 5 wt pet $\mathrm{Ni}$ and $1.5 \mathrm{wt}$ pet $\mathrm{Cu}$, and the hardness was only about HV140. Since no lamellae structures, such as those found in pearlite, and no featherlike structures, such as

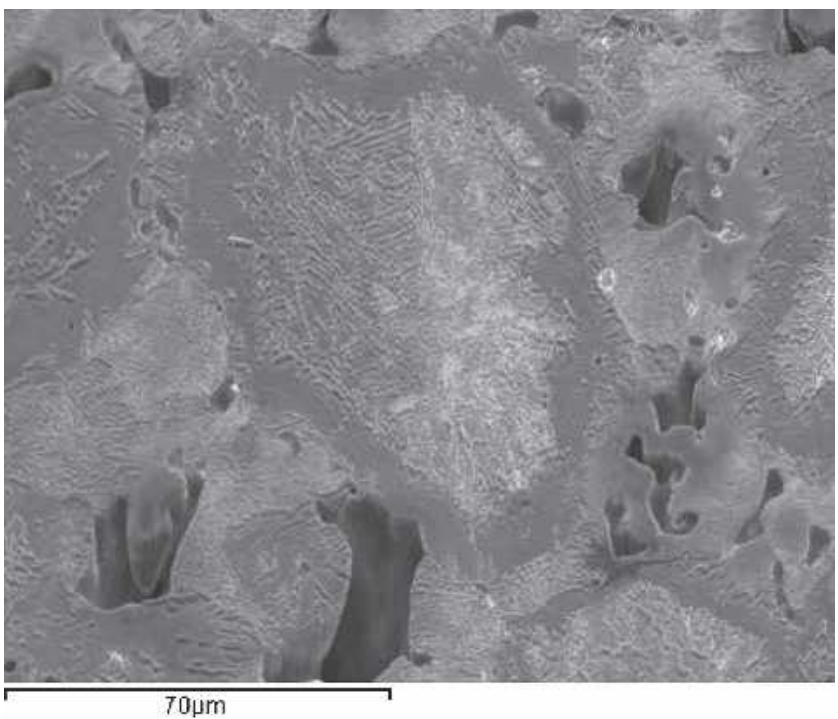

(a)

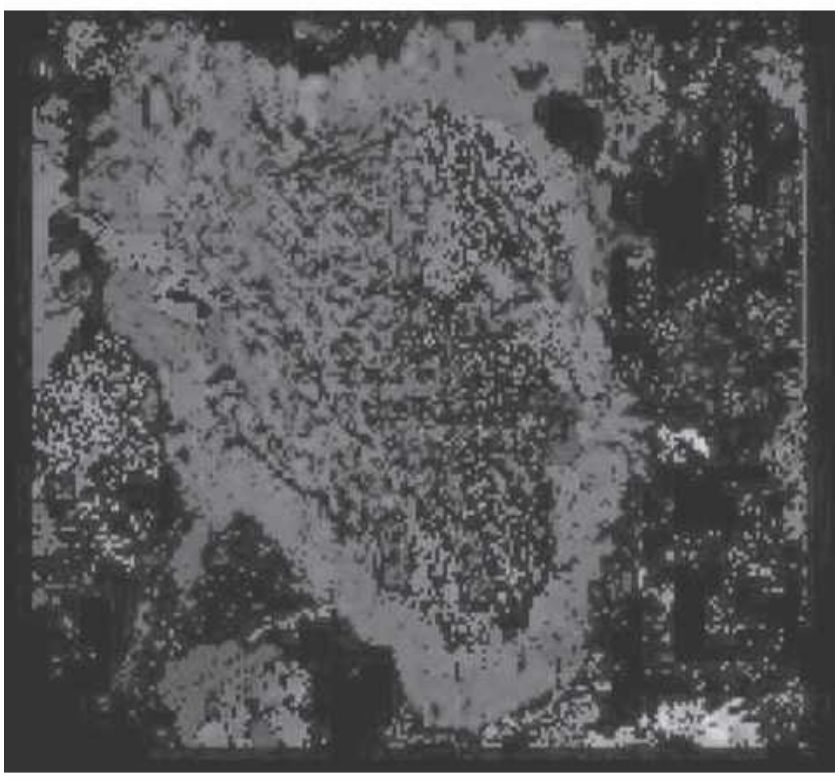

(b)

Fig. 2-The (a) microstructure and (b) EBSD mapping of $\mathrm{Fe}-4 \mathrm{Ni}-1.5 \mathrm{Cu}-$ $0.5 \mathrm{Mo}-0.5 \mathrm{C}$ steels sintered at $1120^{\circ} \mathrm{C}$ for $30 \mathrm{~min}$ showing that the powder periphery areas are ferrites.

those found in bainite or martensite, were found, the microstructure, hardness, and composition of this area made us to believe that it is either ferrite or austenite. Since the phase identification for this powder periphery 
area has not been reported in the literature, EBSD analysis was carried out. The mapping, as shown Figure 2, confirms that these soft powder periphery areas are ferrites.

It was also found that the pore-rich regions were enriched with $\mathrm{Ni}$ and $\mathrm{Cu}$. However, these regions were not ferrites since they did not match the EBSD ferrite mapping. In areas that contained 4 to $8 \mathrm{wt}$ pct $\mathrm{Ni}$ and $2 \mathrm{wt}$ pct $\mathrm{Cu}$, the hardness ranged between HV420 and HV562, similar to that of martensite. In other pore-rich areas, the hardness was low and ranged between HV170 and HV260. These soft areas contained 11 to 23 wt pct Ni and 4 wt pct $\mathrm{Cu}$. It is believed that these areas were austenites because the high $\mathrm{Ni}$ and $\mathrm{Cu}$ content stabilized the austenitic structure down to the room temperature. The EPMA analysis also indicated that the carbon content in the soft Ni-rich area was lower than those in pearlite and martensite. ${ }^{[4]}$ To facilitate the discussion of the soft Ni-rich areas, the soft area at the periphery of the iron powder was designated as Ni-rich area 1, while the soft pore-rich area was designated as Ni-rich area 2.

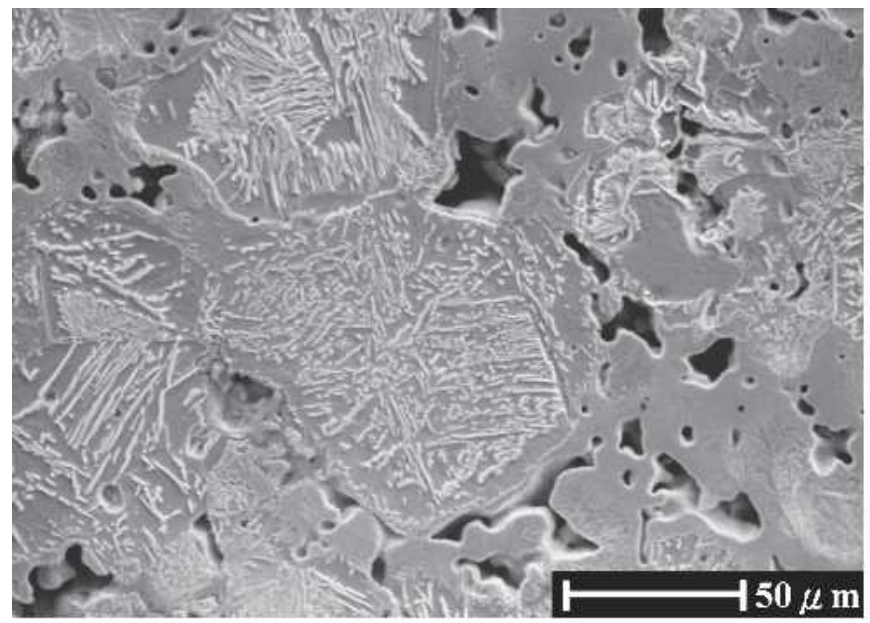

(a)

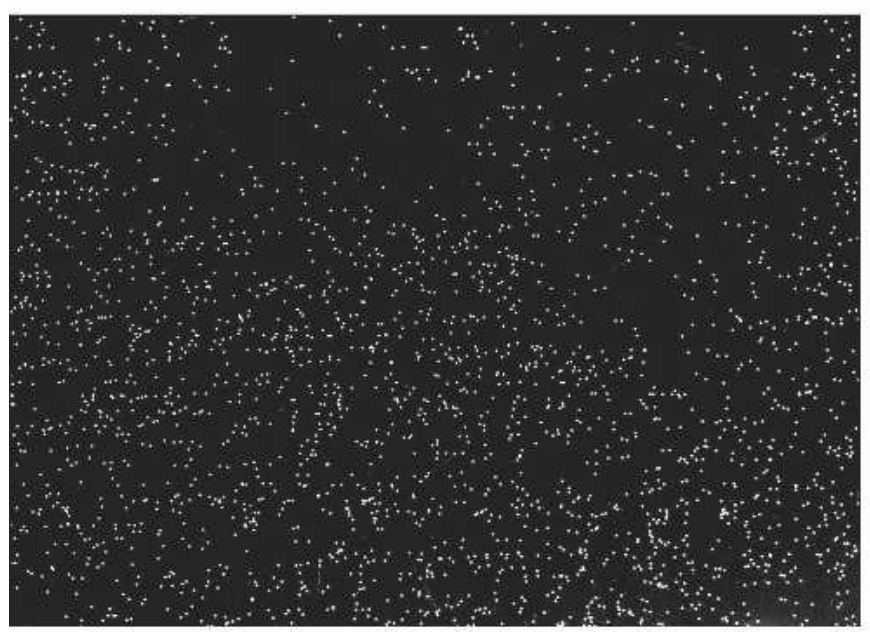

(c)
The inhomogeneity of the alloying was further verified by the mappings of $\mathrm{Ni}, \mathrm{Cu}$, and Mo. Figure 3 shows that molybdenum was uniformly distributed and that its content was between 0.4 and $0.6 \mathrm{wt}$ pct, which was close to the nominal 0.5 pct. Since Mo could be easily homogenized, comparison of Mo mapping was neglected in the following sections. However, the $\mathrm{Cu}, \mathrm{Ni}$, and $\mathrm{C}$ distributions were nonuniform. It is believed that the Ni-rich areas were formed as a result of surface diffusion of $\mathrm{Ni}$ on the iron powders. ${ }^{[13,14,15]}$ Most of the Ni remained near the surface, since its lattice diffusion rate into iron is quite slow. The $\mathrm{Cu}$ distribution was similar to that of $\mathrm{Ni}$ in that it covered the powder surfaces. This was because the copper melted during sintering and penetrated into the interparticle pores and powder contact areas due to the capillary force before it diffused inward to the powder core. ${ }^{[16-19]}$ Since these Ni/ $\mathrm{Cu}$-rich and $\mathrm{C}$-lean areas are low in hardness and their locations are in stress concentration regions, these areas could therefore be the most probable sites of crack initiation during mechanical testing. ${ }^{[6,7,20-22]}$ However, further detailed experiments will be required to identify the phases

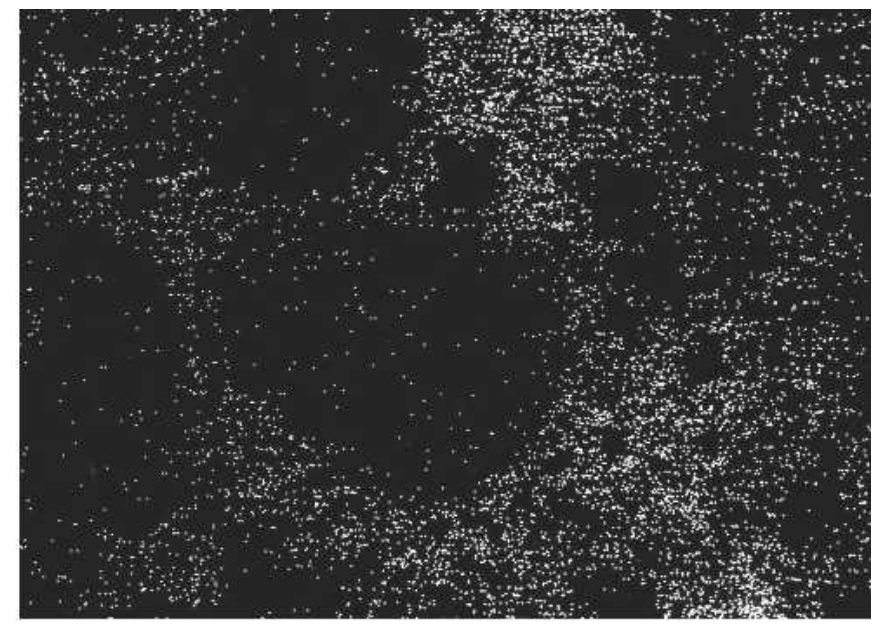

(b)

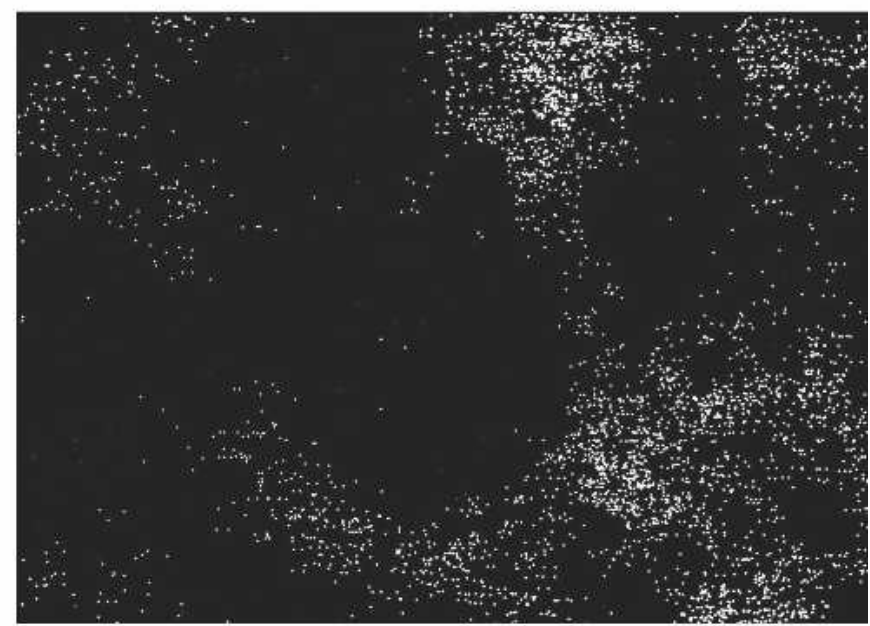

(d)

Fig. 3- $(a)$ through $(d)$ The $\mathrm{Cu}(b)$, Mo $(c)$, and $\mathrm{Ni}(d)$ mappings of the diffusion-alloyed $\mathrm{Fe}-4 \mathrm{Ni}-1.5 \mathrm{Cu}-0.5 \mathrm{Mo}-0.5 \mathrm{C}$ specimen that was sintered at $1120{ }^{\circ} \mathrm{C}$. 


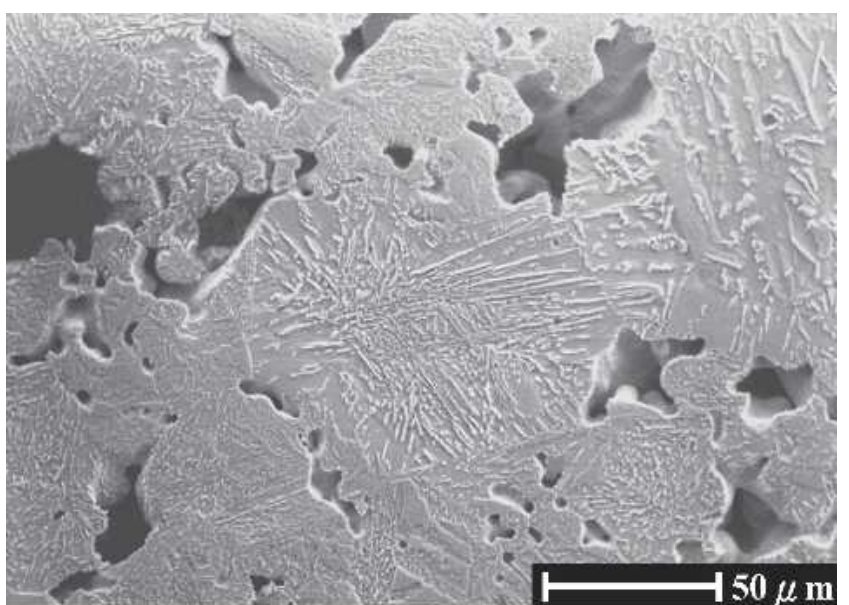

(a)

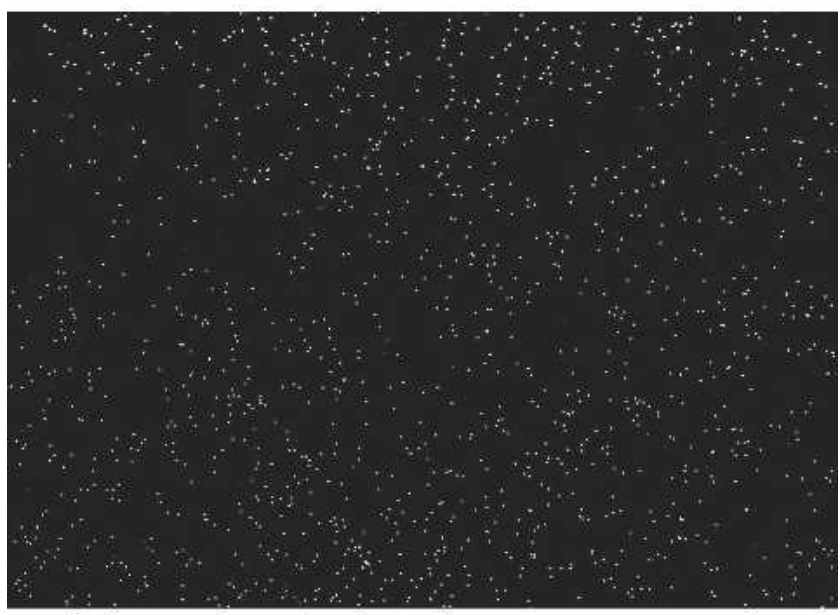

(b)

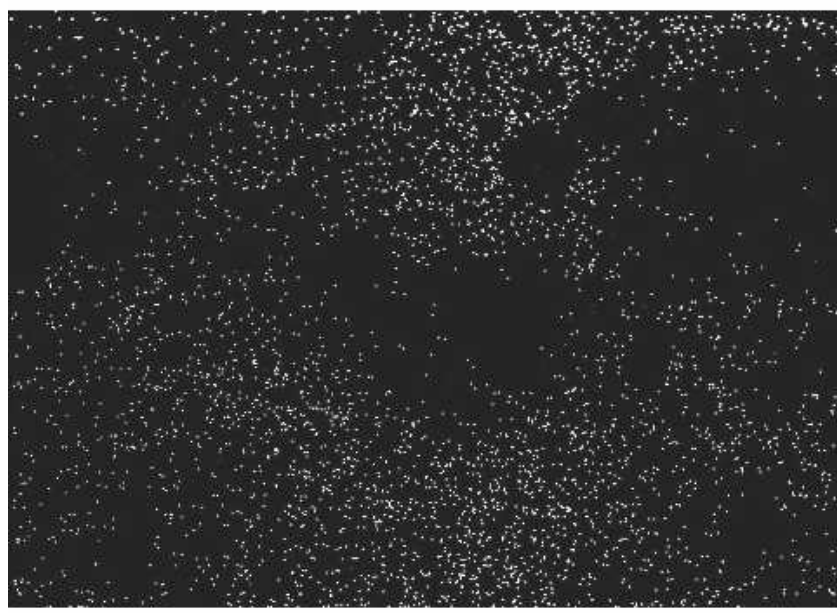

(c)

Fig. 4- (a) through $(c)$ The $\mathrm{Cu}(b)$ and $\mathrm{Ni}(c)$ mappings of the diffusionalloyed $\mathrm{Fe}-4 \mathrm{Ni}-1.5 \mathrm{Cu}-0.5 \mathrm{Mo}-0.5 \mathrm{C}$ specimen that was sintered at $1250{ }^{\circ} \mathrm{C}$.

of these $\mathrm{Ni} / \mathrm{Cu}$ rich areas and to correlate these phases with fracture behaviors.

When the sintering temperature increased to $1250{ }^{\circ} \mathrm{C}$, the microstructure homogeneity improved significantly.

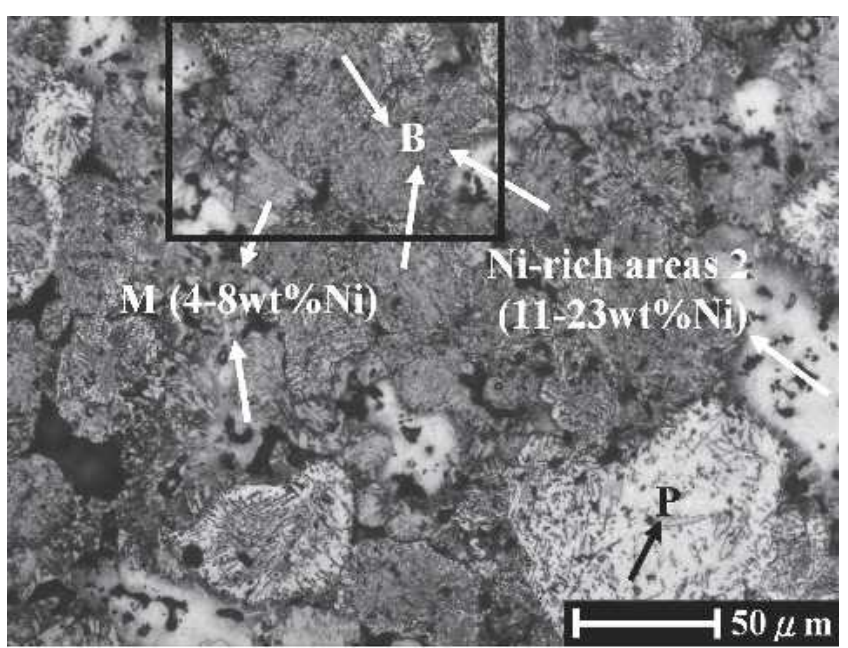

(a)

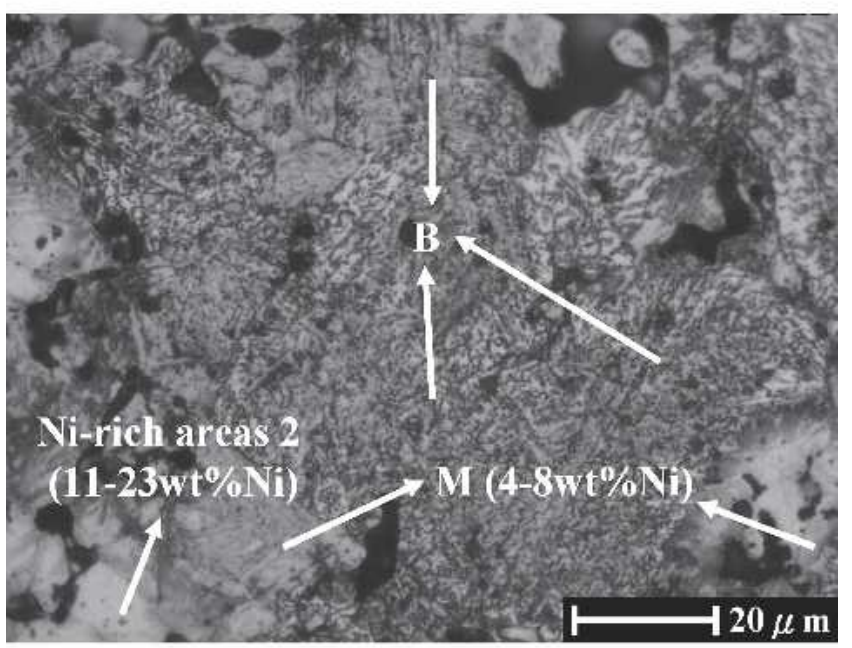

(b)

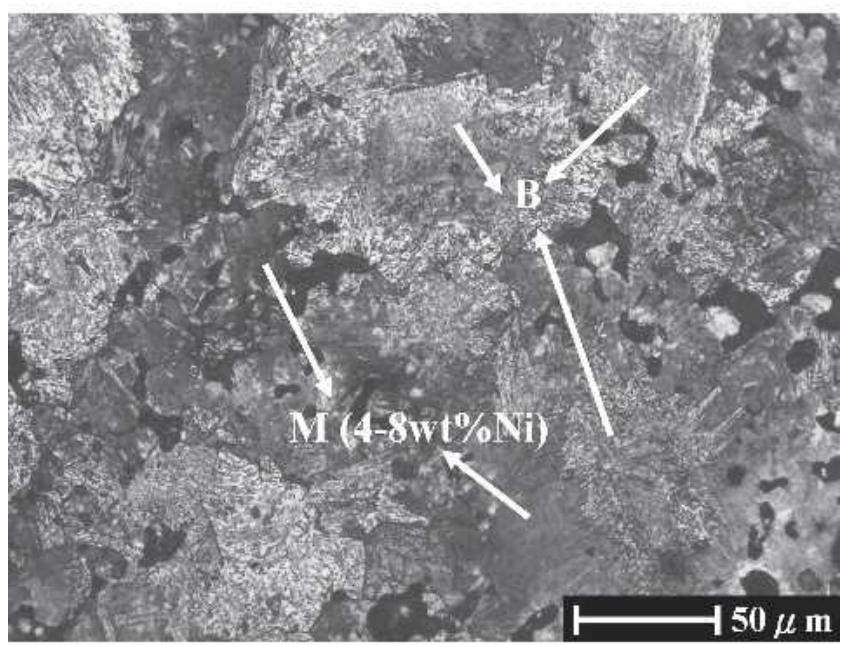

(c)

Fig. 5-The microstructure of the diffusion-alloyed Fe-4Ni-1.5Cu-0.5Mo$0.5 \mathrm{Cr}-0.5 \mathrm{C}$ steels that contained $316 \mathrm{~L}$ powders and were sintered at $(a)$ $1120^{\circ} \mathrm{C}$ for $30 \mathrm{~min},(b)$ an enlarged section of the bainite region, and $(c)$ $1250{ }^{\circ} \mathrm{C}$ for $1 \mathrm{~h}$. 
More fine pearlite and bainite could be found, as shown in Figure 1(b). However, thin Ni-rich areas on the powder surfaces were still present. The mapping of a typical area, as shown in Figure 4, indicated that the $\mathrm{Ni}$ was still not uniformly distributed, even after $1250{ }^{\circ} \mathrm{C}$ sintering. The $\mathrm{Ni}$ content in the powder core was only about 0.1 wt pet.

\section{Microstructure Evolution of Fe-4Ni-1.5Cu-0.5Mo-0.5C $+316 L$ P/M Steels}

Figure 5 shows the typical microstructure of a diffusionalloyed $\mathrm{Fe}-4 \mathrm{Ni}-1.5 \mathrm{Cu}-0.5 \mathrm{Mo}-0.5 \mathrm{C}$ steel to which was added 3 wt pet $316 \mathrm{~L}$ powder (material B) after sintering at $1120{ }^{\circ} \mathrm{C}$ and $1250{ }^{\circ} \mathrm{C}$. The specimen sintered at $1120^{\circ} \mathrm{C}$, as shown in Figures 5(a) and (b), exhibited mainly two phases. The first one had featherlike microstructures and a hardness value between HV 270 and 360. These results suggested that these areas were bainites. The other area had a hardness value between HV427 and HV586, which is in the hardness range of martensite. A small portion of pearlite was also present. The Ni-rich areas in the pore-rich region and at the periphery region of the iron powder were much less pronounced compared to those of material A, as shown in Figure 1(a). After $1250{ }^{\circ} \mathrm{C}$ sintering, the microstructure consisted mainly of bainite and martensite. No soft Ni-rich phases were found. It was also noticed that more pore rounding occurred after $1250{ }^{\circ} \mathrm{C}$ sintering. This pore shape change and the density increase also helped to improve the mechanical properties.

To understand the effect of $\mathrm{Cr}$ addition on the microstructure changes, the mappings of $\mathrm{Cr}, \mathrm{Mo}, \mathrm{Ni}$, and $\mathrm{Cu}$ for specimens that were sintered at $1000{ }^{\circ} \mathrm{C}, 1050{ }^{\circ} \mathrm{C}$, $1120^{\circ} \mathrm{C}$, and $1250{ }^{\circ} \mathrm{C}$ were examined. Figure 6 reveals that no Mo-rich areas were found after the specimen was sintered at $1000{ }^{\circ} \mathrm{C}$, because Mo has a much faster diffusion rate in $\mathrm{Fe}$ compared to those of $\mathrm{Cr}, \mathrm{Ni}$, and $\mathrm{Cu}$. In contrast, $\mathrm{Cr}$-rich, Ni-rich, and $\mathrm{Cu}$-rich areas were present, and these were believed to be the original sites of the alloying powder additives. Figure 6 also reveals that pearlite formed at the periphery of the iron powder, indicating that the carbon had diffused into these regions.

After sintering at $1050{ }^{\circ} \mathrm{C}$, the segregation of $\mathrm{Ni}, \mathrm{Cu}$, and $\mathrm{Cr}$ improved, as shown in Figure 7. The highest local $\mathrm{Cr}$ content found in this specimen was only $7.6 \mathrm{wt}$ pct, much lower than the nominal $16.46 \mathrm{wt}$ pct $\mathrm{Cr}$ in the asreceived $316 \mathrm{~L}$ powder. This result suggested that the chromium oxide on the $316 \mathrm{~L}$ powder surfaces, which was a diffusion barrier, was reduced between $1000{ }^{\circ} \mathrm{C}$ and $1050{ }^{\circ} \mathrm{C}$ in $\mathrm{N}_{2}-9$ petH 2 and caused $\mathrm{Cr}$ diffusion into the iron matrix. This agreed with previous thermodynamic calculations and experimental results reported by others. ${ }^{[11,12]}$ Since $\mathrm{Cr}$, once reduced, has a higher diffusion rate than $\mathrm{Ni}$, it was more uniformly distributed. ${ }^{[8]}$ It was also noticed that pearlites continued to form due to the large solubility of carbon in iron after ferrite-austenite transformation, as reported in the dilatometer studies by St-Laurent et al. ${ }^{[23]}$

When the specimens were sintered at $1120{ }^{\circ} \mathrm{C}$, the distributions of $\mathrm{Ni}$ and $\mathrm{Cu}$, as shown in Figure 8, became more uniform and were significantly improved from those of material $\mathrm{A}$, which did not have $\mathrm{Cr}$ additions, as shown in Figure 3. The distribution of $\mathrm{Cr}$ was also improved. The quantitative analysis indicated that the $\mathrm{Cr}$ contents in the

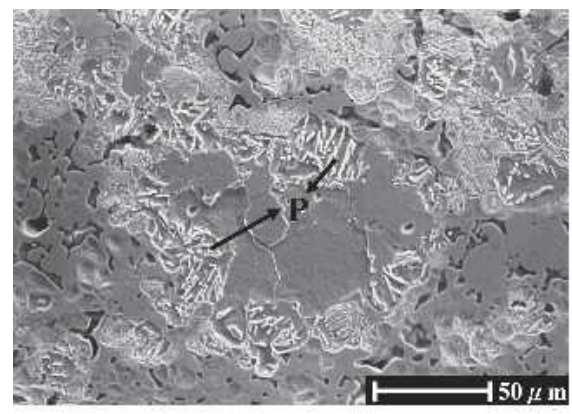

(a)

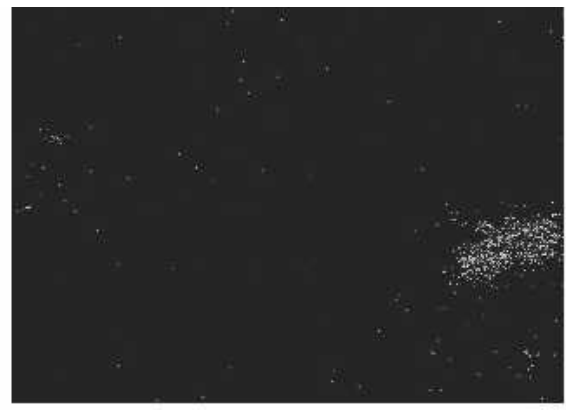

(b)

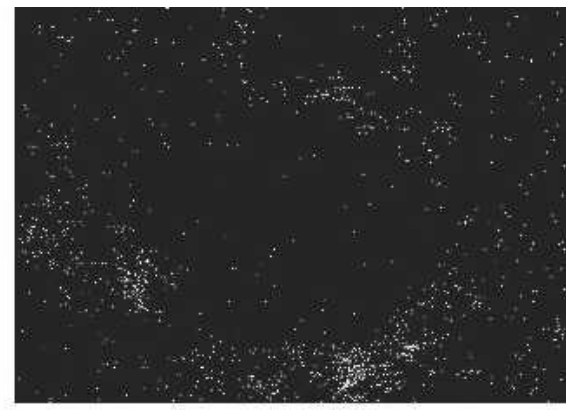

(c)

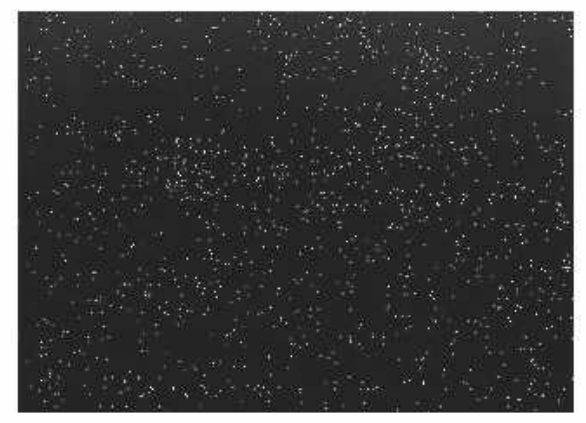

(d)

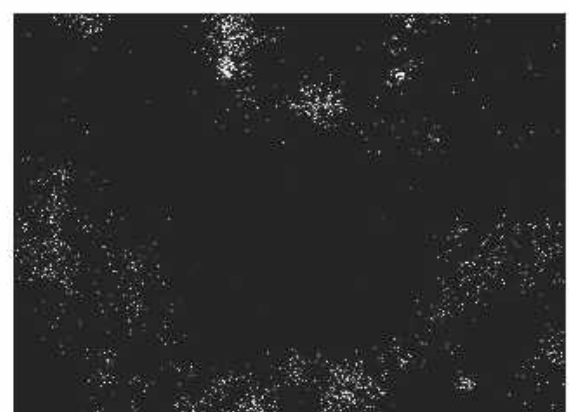

(e)

Fig. 6- $(a)$ through $(e)$ The mappings of $\mathrm{Cr}(b), \mathrm{Cu}(c)$, Mo $(d)$, and Ni $(e)$ in the diffusion-alloyed specimen that was mixed with $316 \mathrm{~L}$, showing that most $\mathrm{Ni}, \mathrm{Cu}$, and $316 \mathrm{~L}$ powders remain in the powder form after $1000{ }^{\circ} \mathrm{C}$ sintering for $30 \mathrm{~min}$. 


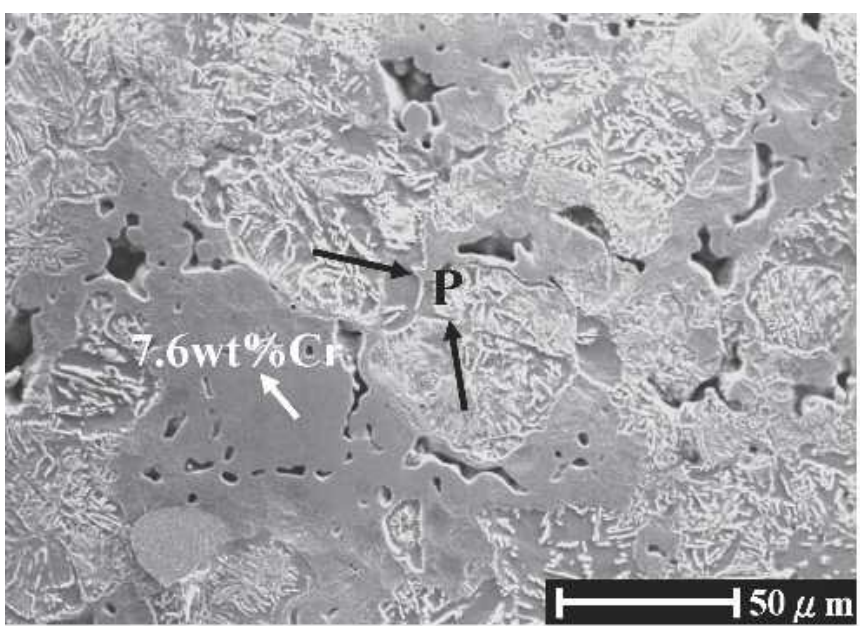

(a)

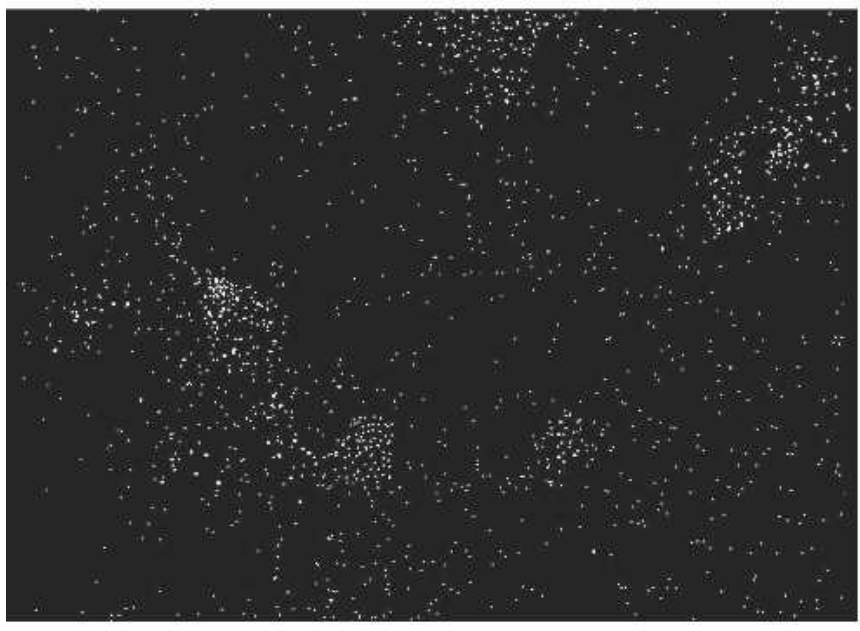

$(c)$

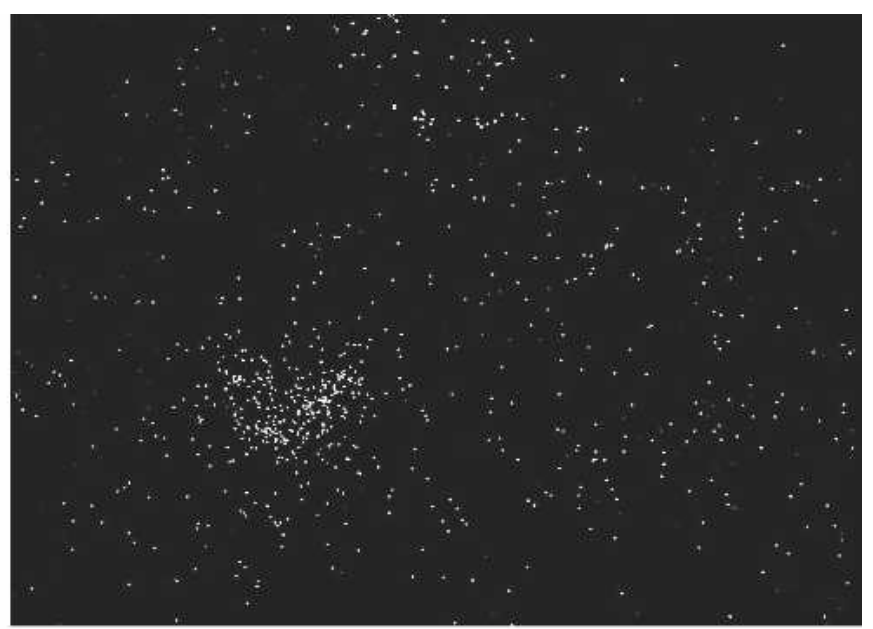

(b)

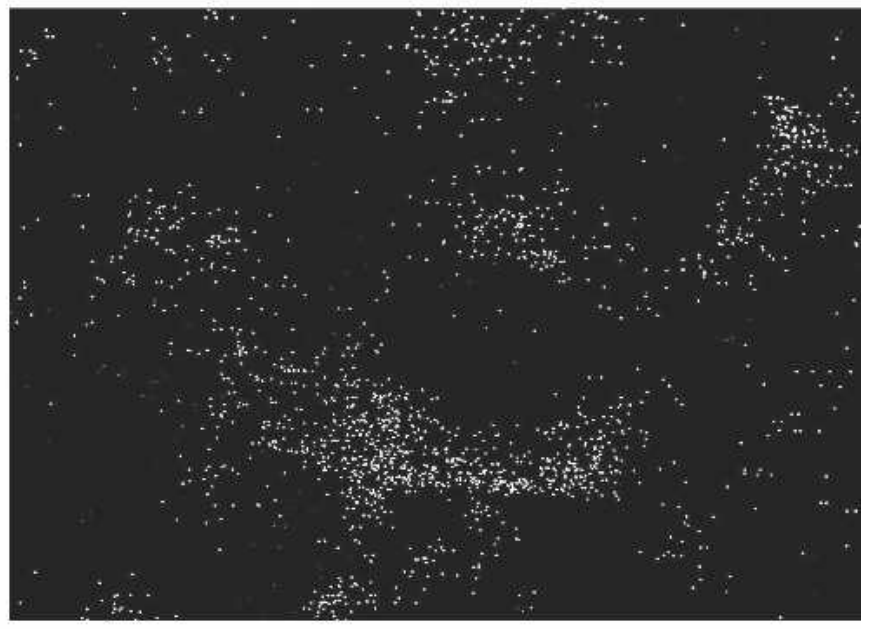

(d)

Fig. 7- $(a)$ through $(d)$ The mappings of $\mathrm{Cr}(b), \mathrm{Cu}(c)$, and $\mathrm{Ni}(d)$ in the diffusion-bonded steel that was mixed with $316 \mathrm{~L}$ powder, showing that $\mathrm{Cr}$ and $\mathrm{Cu}$ had diffused into the matrix after $1050{ }^{\circ} \mathrm{C}$ sintering for $30 \mathrm{~min}$.

interior and at the periphery of the iron powder were about 0.1 and $1 \mathrm{wt}$ pct, respectively.

The mappings in Figure 9 show that the homogeneity of $\mathrm{Cr}, \mathrm{Ni}$, and $\mathrm{Cu}$ had been significantly improved after $1250{ }^{\circ} \mathrm{C}$ sintering for 1 hour. The $\mathrm{Cr}$ content measured using EPMA indicated that the Cr was very uniformly distributed throughout the matrix and was about $0.5 \mathrm{wt}$ pet. The Ni distribution also improved. Its content in the iron powder core increased to about 0.4 wt pct, as compared to the $0.1 \mathrm{wt}$ pct in the similar region for material A.

To further confirm the effect of $\mathrm{Cr}$ addition on alloying homogenization, the line scans of $\mathrm{C}, \mathrm{Ni}, \mathrm{Cu}$, and $\mathrm{Cr}$ on typical iron particles that were sintered at $1250{ }^{\circ} \mathrm{C}$ were examined. Figure 10(a) shows that the iron powder core contained high $\mathrm{C}$ and low $\mathrm{Ni}$, while the surface region contained low $\mathrm{C}$ and high Ni. This nonuniform distribution of $\mathrm{Ni}$ and $\mathrm{C}$ is caused by the strong repelling effect, as reported by Sozinov and Gavrilijuk. ${ }^{[9]}$ Through ThermoCalc program calculations, they indicated that the presence of $\mathrm{Ni}$ or $\mathrm{Si}$ in austenite increases the chemical potential of carbon and thus decreases the equilibrium carbon content in the austenite. ${ }^{[2]}$ With a low carbon and high $\mathrm{Ni}$ content, no bainite or martensite could be found in these Ni-rich/C-lean areas after cooling. Such inhomogeneous microstructures could still be found, as shown in Figure 1(b), even after $1250{ }^{\circ} \mathrm{C}$ sintering. When 316L stainless steel powders were added to introduce $0.5 \mathrm{pct}$ $\mathrm{Cr}$, the differences of $\mathrm{Ni}$ and $\mathrm{C}$ content between the surface and the core region diminished, as demonstrated in Figure 10(b).

To correlate the microstructures with the mechanical properties presented previously, a CCT graph was constructed, as shown in Figure 11. As indicated by the CCT curves, pearlites, bainites, and martensites should be present in FD-0405 specimens. With the addition of 0.5 pct $\mathrm{Cr}$, the CCT curve shifted to the right side because the multiplying factor of hardenability increased by approximately 2.1 times. $^{[25]}$ As a result, only bainites and martensites would be present when a cooling rate of $0.1{ }^{\circ} \mathrm{C} / \mathrm{s}$ was employed. These results agreed with the 


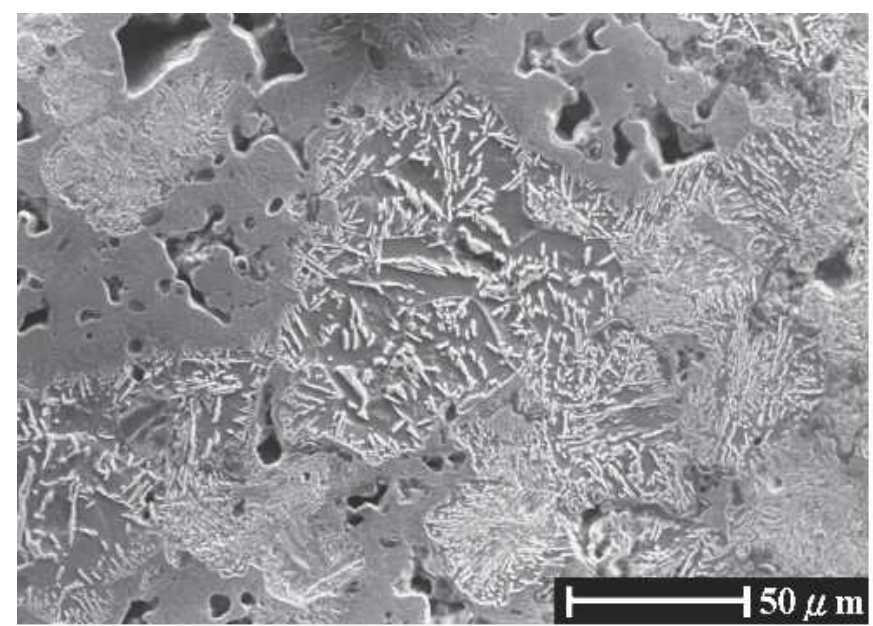

(a)

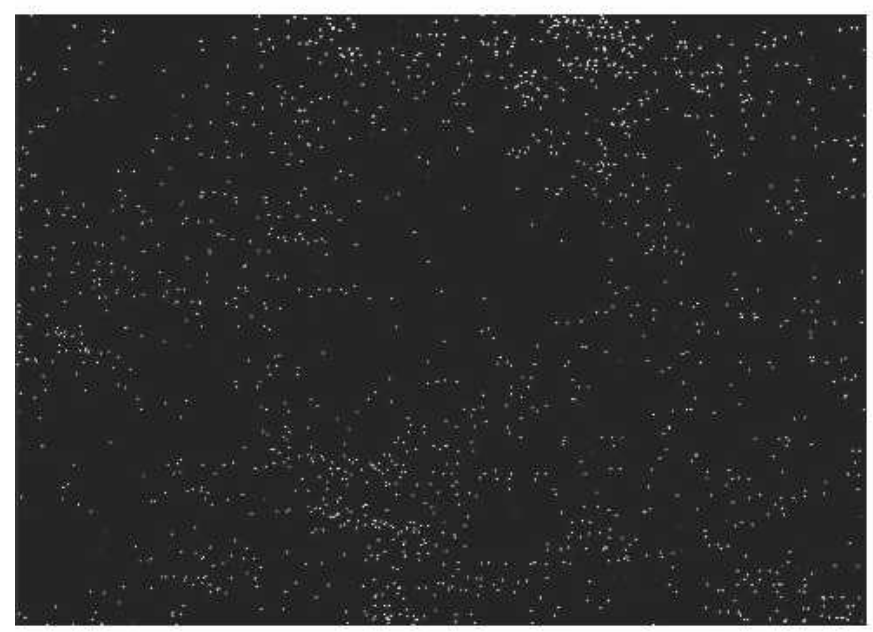

$(c)$

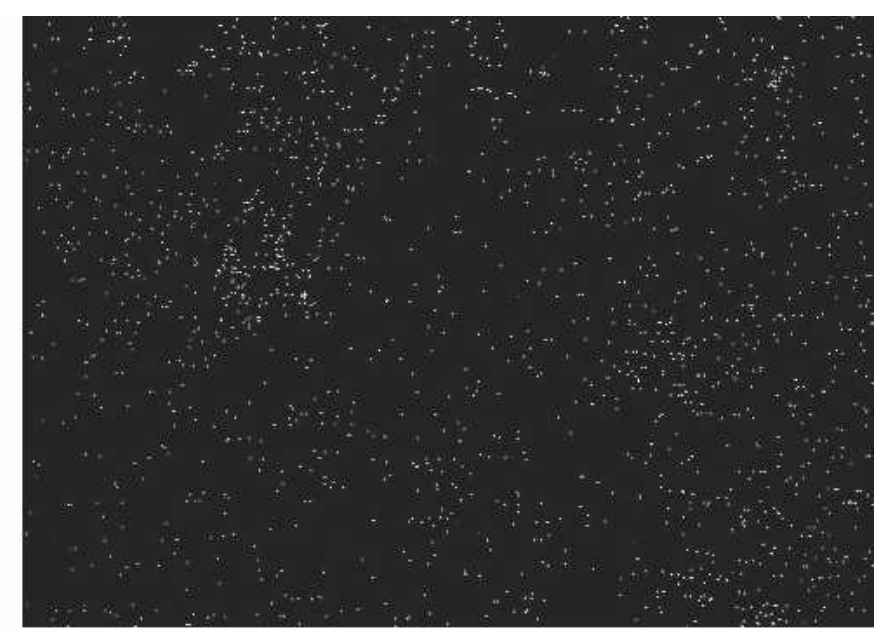

(b)

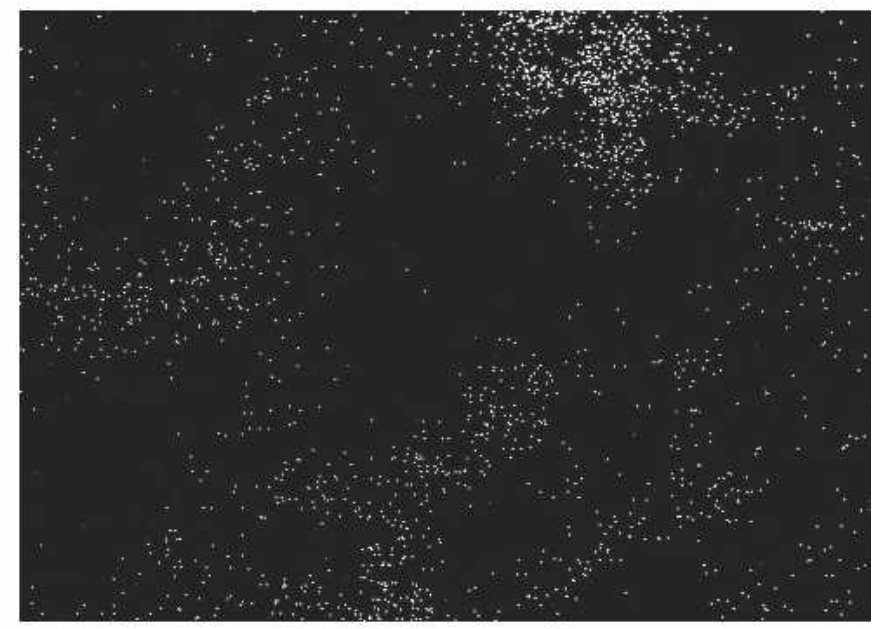

$(d)$

Fig. 8- (a) through $(d)$ The mappings of $\mathrm{Cr}(b), \mathrm{Cu}(c)$, and $\mathrm{Ni}(d)$ in diffusion-bonded steels mixed with $316 \mathrm{~L}$ powder after $1120{ }^{\circ} \mathrm{C}$ sintering for $30 \mathrm{~min}$.

microstructures observed and the mechanical properties attained.

The preceding observations suggest that the presence of $\mathrm{Cr}$, which is a strong carbide former, can help improve the distribution of carbon and nickel in the matrix. It also increases the multiplying factor of hardenability. Thus, more bainites and martensites form, and the soft Ni-rich areas are eliminated. With these encouraging results from adding $\mathrm{Cr}$ into $\mathrm{Ni}$-containing specimens, it should be plausible to use a prealloyed $\mathrm{Fe}-\mathrm{Cr}$ powder as the base powder to further enhance the beneficial effect of $\mathrm{Cr}$ addition. It is believed that, with the $\mathrm{Cr}$ being uniformly distributed in the prealloyed powder, the homogenization of $\mathrm{C}$ and $\mathrm{Ni}$ and the mechanical properties should be further improved. Work on this subject is now under way.

\section{CONCLUSIONS}

The addition of 0.5 wt pct $\mathrm{Cr}$, introduced in the $316 \mathrm{~L}$ powder form, improves the alloy homogeneity of diffu- sion-alloyed $\mathrm{Fe}-4 \mathrm{Ni}-1.5 \mathrm{Cu}-0.5 \mathrm{Mo}-0.5 \mathrm{C} \quad \mathrm{P} / \mathrm{M}$ steels. When $1250{ }^{\circ} \mathrm{C}$ sintering is employed, the ultimate tensile strength of the tensile bar in the as-furnace-cooled condition increases from 626 to $801 \mathrm{MPa}$, a $28 \mathrm{pct}$ increase. The microstructure of the sintered steel without $\mathrm{Cr}$ additions shows that $\mathrm{Ni}$ is the least homogenized element and is concentrated in the pore-rich regions or in the surface region of iron powders. The presence of $\mathrm{Ni}$ in these areas reduces the carbon content and forms soft Ni-rich phases, which become the most likely sites of crack initiation and cause failures during mechanical testing. This problem is solved with the addition of $\mathrm{Cr}$, particularly in combination with the $1250{ }^{\circ} \mathrm{C}$ hightemperature sintering. The presence of $\mathrm{Cr}$ eliminates soft $\mathrm{Ni}$-rich areas. When $1120{ }^{\circ} \mathrm{C}$ is used, some residual $\mathrm{Ni}$ rich areas are still present. However, the carbon content is higher than that of $\mathrm{Cr}$-free compacts due to the lessening of the repelling effect between $\mathrm{Ni}$ and $\mathrm{C}$. With more homogenized $\mathrm{Ni}$ and $\mathrm{C}$ and thus more bainite and martensite present, the tensile strength and hardness are improved. 


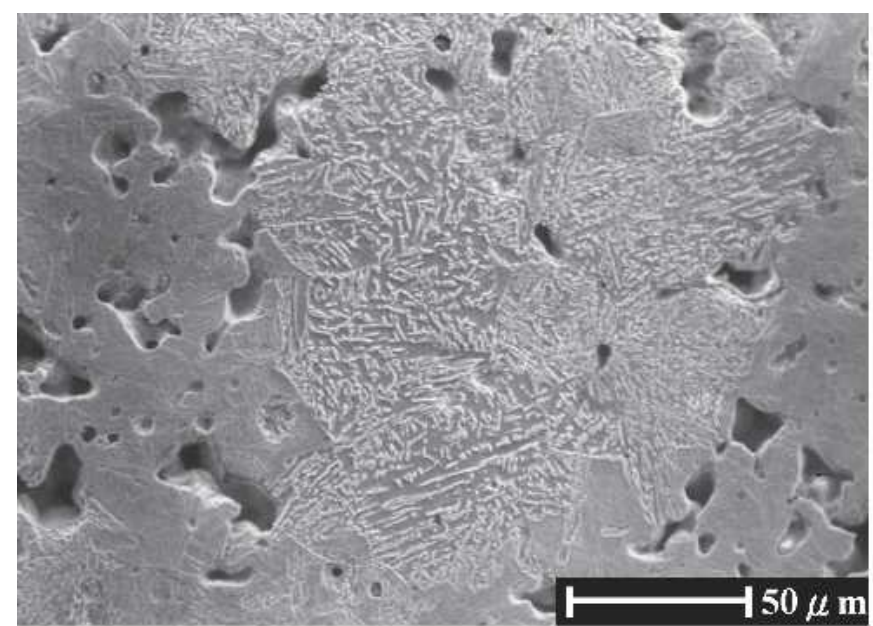

(a)

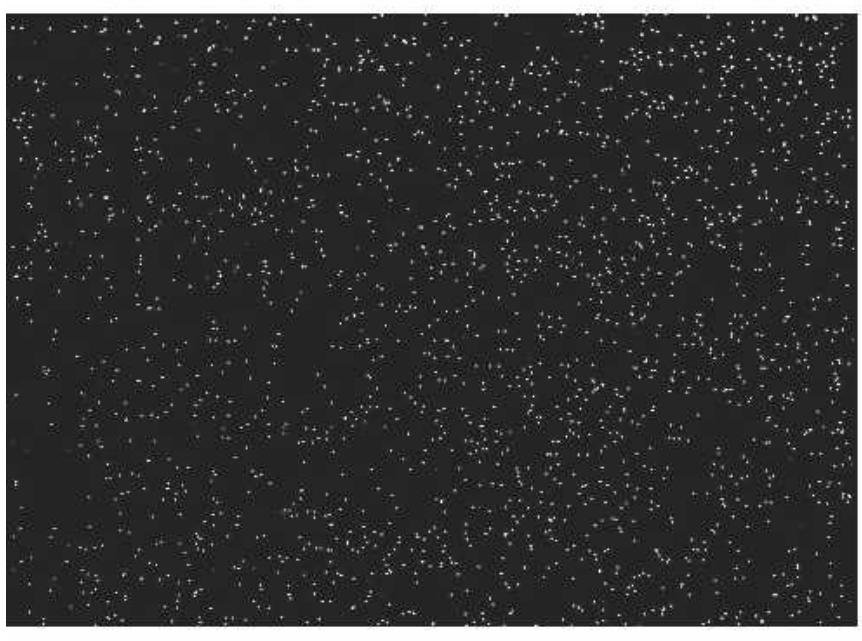

(c)

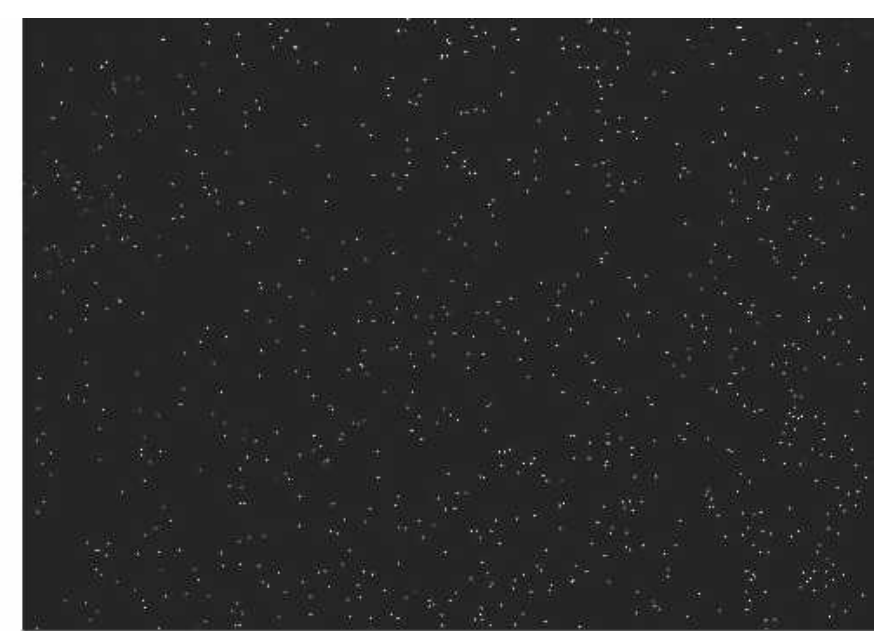

(b)

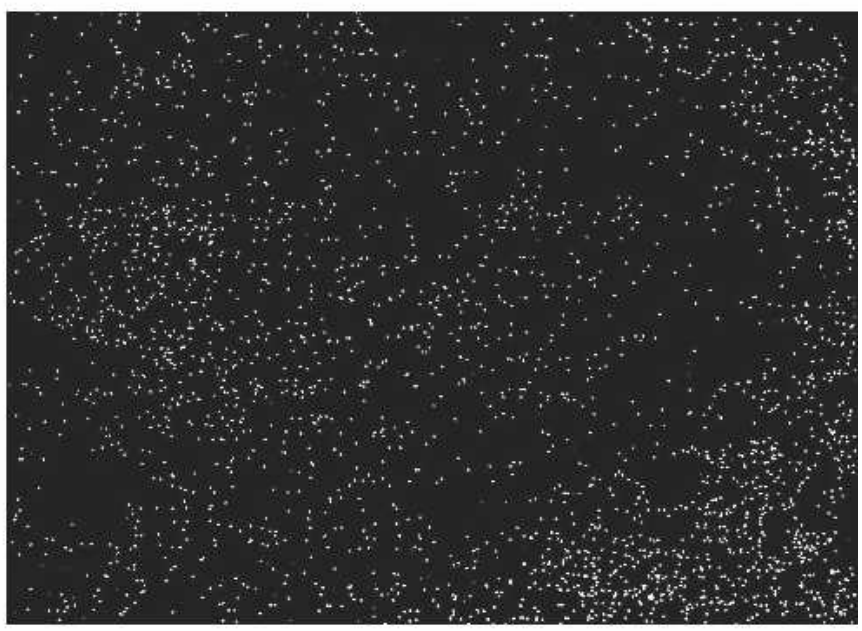

(d)

Fig. 9- (a) through $(d)$ The mappings of $\mathrm{Cr}(b), \mathrm{Cu}(c)$, and $\mathrm{Ni}(d)$ in diffusion-bonded steels mixed with $316 \mathrm{~L}$ powder after $1250{ }^{\circ} \mathrm{C}$ sintering for $1 \mathrm{~h}$.

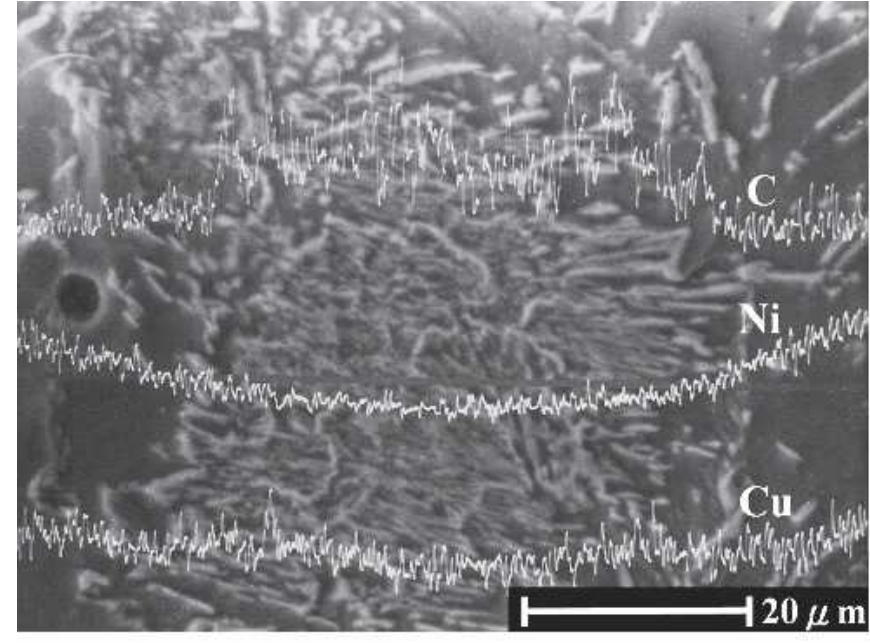

(a)

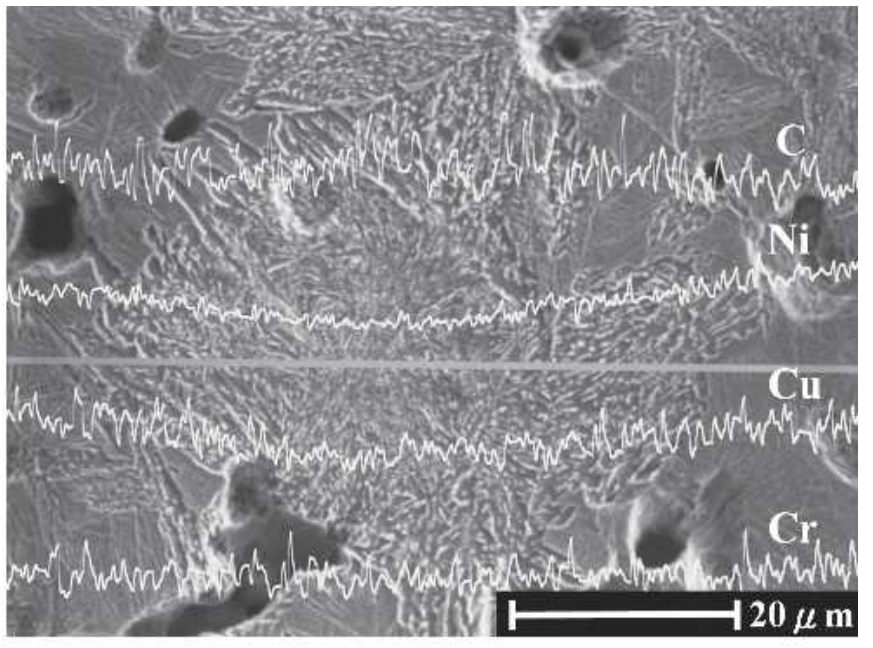

(b)

Fig. 10-The line scans of $\mathrm{Ni}, \mathrm{Cu}$, and $\mathrm{C}$ around a typical powder for (a) FD-0405 sintered steel and (b) an FD-0405 specimen mixed with 3 pct $316 \mathrm{~L}$ powder after $1250{ }^{\circ} \mathrm{C}$ sintering, showing that $\mathrm{Cr}$ addition helps the homogenization of alloying elements, particularly the carbon. 


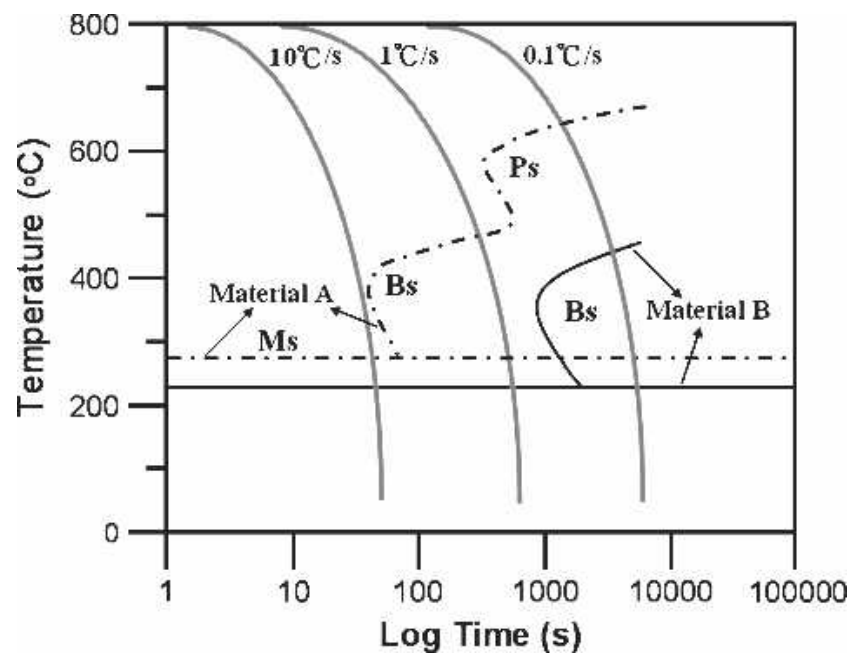

Fig. 11-The CCT graph of FD-0405 and FD-0405 with the addition of 3 pct 316L powders.

\section{ACKNOWLEDGMENT}

The authors thank the Hoeganaes Corp. for their support of this project under Contract No. 91-S-A57.

\section{REFERENCES}

1. R. Haynes: Powder Metall., 1989, vol. 32 (2), pp. 140-46.

2. M. Khaleghi and R. Haynes: Powder Metall., 1985, vol. 28 (4), pp. 217-23.

3. S. Berg: Adv. Powder Metall. Part. Mater, compiled by C.L. Rose and M.H. Thibodeau, MPIF, Princeton, NJ, 1999, vol. 2 (part 7), pp. $163-69$.

4. N. Douib, I.J. Mellanby, and J.R. Moon: Powder Metall., 1988, vol. 32 (3), pp. 209-14

5. E. Dudrova, M. Kabatova, and M. Kupkova: Kov. Mater, 2002, vol. 40, pp. 24-33.
6. C. Verdu, S. Carabajar, G. Lormand, and R. Fougeres: Mater. Sci. Eng., 2001, vols. 319A-321A, pp. 544-49.

7. S. Carabajar, C. Verdu, A. Hamel, and R. Fougeres: Mater. Sci. Eng., 1998, vol. 257A, pp. 225-34

8. R.C. Weast and M.J. Astle: CRC Handbook of Chemistry and Physics, 61st ed., CRC Press, Boca Raton, FL, 1980-1981, p. F-65.

9. A.L. Sozinov and V.G. Gavrilijuk: Scripta Mater, 1999, vol. 41 (6), pp. 679-83.

10. K. Kanno and Y. Takeda: Adv. Powder Metall. Part. Mater., compiled by V. Arnhold, C.L. Chu, W.F. Jandeska, and H.I. Sanderow, MPIF, Princeton, NJ, 2002, vol. 2 (part 13), pp. 14-22.

11. P. Ortiz and F. Castro: Powder Metall., 2004, vol. 47 (3), pp. 291-98.

12. B. Lindqvist and K. Kanno: Adv. Powder Metall. Part. Mater. compiled by V. Arnhold, C.L. Chu, W.F. Jandeska, and H.I. Sanderow, MPIF, Princeton, NJ, 2002, part 13, pp. 278-90.

13. K.S. Hwang and M.Y. Shiau: Metall. Mater. Trans. B, 1996, vol. 27B, pp. 203-11.

14. P.F. Stablein, Jr. and G.C. Kuczynski: Acta Metall., 1963, vol. 11 (3), pp. 1327-37.

15. J. Puckert, W.A. Kaysser, and G. Petzow: Int. J. Powder Metall., 1984 , vol. 20 (4), pp. 301-10.

16. S.J. Jamil and G.A. Chadwick: Powder Metall., 1985, vol. 28 (2), pp. 65-71.

17. H. Kuroki, G. Han, and K. Shinozaki: Int. J. Powder Metal. Powder Technol., 1999, vol. 32 (2), pp. 57-62.

18. R.L. Lawcock and T.J. Davies: Powder Metall., 1990, vol. 33 (2), pp. $147-50$.

19. C.T. Huang and K.S. Hwang: Powder Metall., 1996, vol. 39 (2), pp $119-23$

20. N. Chawla and X. Deng: Mater. Sci. Eng., 2005, vol. 390A, pp. 98112.

21. W.A. Spitzig, R.E. Semlser, and O. Richmond: Acta Metall., 1988, vol. 36 (5), pp. 1201-11.

22. R.J. Bourcier, D.A. Koss, R.E. Smelser, and O. Richmond: Acta Metall., 1986, vol. 34 (12), pp. 2443-53.

23. S. St-Laurent, P. Lemieux, and S. Pelletier: Adv. Powder Metall. Part. Mater, compiled by W.B. James and R.A. Chernenkoff, MPIF, Princeton, NJ, 2004, part 10, pp. 145-59.

24. D.A. Porter and K.E. Easterling: Phase Transformations in Metals and Alloys, 2nd ed., CRC Press, Boca Raton, FL, 1992 pp. 96-98.

25. W.F. Smith: Structure and Properties of Engineering Alloys, 2nd ed., McGraw-Hill Co., New York, NY, 1993, pp. 136-37. 